\title{
Editorial
}

\section{Qualidade e visibilidade: requisitos de uma revista de referência}

A revista Psicologia Escolar e Educacional desde seu primeiro fascículo em 1996, sob a coordenação da Profa ${ }^{2}{ }^{a}$ Geraldina Porto Witter, teve por objetivo revelar à comunidade científica sua produção e aos profissionais da Psicologia as experiências bem sucedidas da área, garantindo assim seu registro histórico e documental. A princípio, tal missão era tida por muitos como apenas um sonho, mas, tendo como editora àquela cuja competência e determinação são a marca de sua trajetória profissional, o periódico referência da Psicologia Escolar e Educacional do Brasil e América Latina completou em 2008 seus 12 ininterruptos anos de publicação.

Coube a todos os editores que a sucederam à tarefa de manter a qualidade e ampliar a visibilidade do periódico. Assim, contando com o apoio dos colegas que compuseram o Conselho e Corpo Editorial, bem como com os pareceristas ad hoc e, especialmente com a confiança dos autores que encaminharam seus manuscritos para publicação, temos hoje, a reconhecida qualidade da comunidade científica pelas avaliações do Qualis - periódicos e o apoio editorial do CNPq e parceria incondicional da Casa do Psicólogo.

E a visibilidade? Escolhemos conquistá-la partilhando integralmente todas as informações da revista impressa pela publicação de todos os fascículos on line na base de dados PePSIC com texto completo disponível. Ao lado disso, definimos como parceiros da revista todos os cursos de graduação e Pós-Graduação em Psicologia a quem enviamos desde 2005 todos os volumes publicados. O Sistema Conselhos de Psicologia, Fundações, Organizações Não-Governamentais e Sociedades Científicas também recebem o periódico. Estabeleceu-se uma política de permuta com periódicos nacionais, internacionais e estrangeiros, em especial os de língua portuguesa e os localizados na América Latina, a partir de 2006 . Tais ações possibilitaram que pudéssemos ampliar o rol de indexadores da revista, passando a contar em 2008 com a inclusão no CLASE, do México. Aguardamos a avaliação da SciElo Brasil, PsicoDoc e REDALYC acerca da possibilidade de indexação.

Considerando que se faz necessário renovar para continuar uma trajetória de sucesso, despeço-me como editora da Psicologia Escolar e Educacional neste volume 12. Agradeço a todos que contribuíram em cada etapa da editoração à publicação, sem os quais não teríamos avançado tanto em tão pouco tempo e com os parcos recursos de que dispomos como entidade científica. Acredito, hoje, com mais certeza do que quando iniciei minha trajetória como colaboradora da revista, auxiliando a Prof ${ }^{a}$ Geraldina com o processo editorial, nos idos de 2000 , que a qualidade e visibilidade, requisitos essenciais a um periódico científico, de fato, se conquista pela paixão daqueles que neste processo se envolvem.

Finalizo, pois, agradecendo nominalmente àqueles os quais elegi como representantes de todos os colaboradores e parceiros que acreditaram na importância da Psicologia Escolar no Brasil e, portanto, dedicaram-se incondicionalmente a esse periódico durante minha gestão como editora - $\operatorname{Prof}^{\mathrm{a}} \mathrm{Dr}^{\mathrm{a}}$ Geraldina Porto Witter e Prof ${ }^{\mathrm{a}} \mathrm{Dr}^{\mathrm{a}}$ Acácia Aparecida Angeli dos Santos que me ensinaram a ser editora e são representantes de um Conselho Editorial atuante e dedicado ; Prof ${ }^{a} \mathrm{Dr}^{\mathrm{a}}$ Denise de Sousa Fleith, Prof ${ }^{\mathrm{a}} \mathrm{Dr}^{\mathrm{a}}$ Evely Boruchovitch e Prof ${ }^{\mathrm{a}} \mathrm{Dr}^{\mathrm{a}}$ Marilene Proença Rebello de Souza por dividirem comigo a árdua tarefa de editoração; Lucicleide Maria de Cantalice, Cláudia Martins e Anelise Silva Dias pelo apoio dedicado e competente na administração editorial; Fábian Marin pelo resumen e marcação eletrônica e Thiago Joly pela revisão dos abstracts; e à Casa do Psicólogo, representada por seu diretor Ingo Gunther, que encerrava o processo editorial ao imprimir cada fascículo. A todos aqui mencionados e àqueles a quem representam, meu mais sincero muito obrigada!

M. Cristina. Rodrigues Azevedo Joly Editora 